\title{
High-Performance Work Practices: Extent of Implementation and Commitment in Higher Education Institutions
}

\author{
Edison B. Estigoy ${ }^{1 *}$, Saddam C. Bazer ${ }^{2}$, Jeande A. Jimenez ${ }^{3}$, Joselle D. Pineda ${ }^{4}$, Samantha O. Zabala ${ }^{5}$ \\ ${ }^{I} X i$ 'an International Studies University \\ ${ }^{2}$ Shaanxi Normal University \\ 3,4,5 Awesome Children Education
}

\begin{abstract}
This study explored on high-performance work practices (HPWP) extent of implementation and affective commitment in Higher Education Institutions (HEIs). A descriptive-quantitative design was utilized to determine the extent to which employees perceive that the organization implements HPWP in terms of ability, motivation and opportunity; and the perception of the employees towards affective commitment in HEIs. The empirical data of the study was based on the responses from seventy (70) teachers in HEIs. Findings revealed in general that employees perceived that the organization always implement high-performance work practices in terms of ability and motivation but only often in opportunity. Additionally, respondents agree that teachers are affectively committed to their organizations. Furthermore, HEIs recognize the importance of implementing high-performance work practices and that it affects the affective commitment of the employees. Employees with strong affective commitment will continue to work in the organization and will lead to fewer turnovers.
\end{abstract}

Keywords: High Performance Work Practices, Affective Commitment, Higher Education Institutions, Ability, Motivation and Opportunity

\section{INTRODUCTION}

$\mathrm{H}$ uman Resource Management (HRM) assumes a significant part in permitting a firm to stay serious, and it has been progressively perceived by researchers and experts the same as of late (Ubeda-García et al., 2013). Supervisors are therefore going to the HRM capacities to help execute the serious technique (Ulrich, 1997). Certain HRM practices are claimed to help better firm exhibitions (Jackson and Schuler, 1995; Huselid, 1995). As indicated by Butts et al. (2009), in the course of recent many years, there has been a multiplication of exploration and practices related with such participatory work frameworks. One such participatory work framework is High-Performance Work Practices (HPWP) differently called 'high contribution', 'high commitment', or 'refined' (Guthrie, Spell, and Nyamori 2002) - which alludes to a bunch of practices pointed toward improving employees' abilities, inspiration, data, and strengthening to acquire upper hand (Guthrie, 2001). The idea of HPWP was begun in the United States around 1970's and 1980's. With the ascent of Japanese 'Lean-Production' frameworks, US firms found that their HRM frameworks didn't fit with their serious setting
(Dayarathna, 2012). Subsequently, US firms embraced this idea to acquire an upper hand over the business. This heap of practices looks to cultivate worker contribution in dynamic and critical thinking, upgrade employees' commitment, and eventually increment firm execution (Guthrie, Spell, and Nyamori, 2002; Pil and MacDuffie, 1996). Countless organizations, specifically the private business, are slanted towards planning and actualizing High-Performance Work Practices (HPWPs) to improve organizational execution and profitability. In the current investigation, the model used to clarify the HPWPs is the ability, motivation, and opportunity (AMO) model. It suggests that HPWPs improve the workers' capacity and abilities to play out their work, inspiring them to dominate and accomplish and the chance to share could prompt positive results for the association. These three components add to building maintainable employees' execution. Human Resource frameworks that cultivate capacity, inspiration, and chance to partake will be the best. It is in the previously mentioned specifics, the researchers are intrigued to decide the degree to which workers see that the association actualizes HPWPs regarding ability, motivation, and opportunity and the impression of the employees towards affective commitment in HEIs.

This investigation investigated the degree of usage of HighPerformance Work Practices (HPWPs) in higher education institutions. In this investigation, HPWPS are conceptualized and operationalized as comprising of the ideal and genuine human asset practices in the organization. It incorporates researching the determinant and builds of High-Performance Work Practices (HPWPs), the effect or impact of HPWPs on execution, potential mediations required, and the ability, motivation, and opportunity model. The focal point of this investigation adjusts the idea on the real high-performance work practices.

\section{Statement of the Problem}

The purpose of this study is to explore high-performance work practices and the affective commitment of the employees in the workplace. Particularly the study seeks to answer the following questions: 
1. What is the extent to which employees perceive that the organization implements High-Performance Work Practices in terms of Ability, Motivation, and Opportunity?

2. What is the perception of the employees towards affective commitment in higher education institutions?

\section{Related Literature}

High-Performance Work Practices are 'bundles' or 'systems' that comprise of various judicious practices and it is imperative to recognize the fundamental standards of fruitful execution of High-Performance Work Practices (HPWPs) in an association.

Generally, employees don't request or get a lot of data from the board. Nonetheless, in the present climate, with more client focused choices being pushed down to the forefront level employees, all levels require admittance to more data from an assortment of sources. High-Performance Work Practices (HPWP), hence, gives not just the self-governance to get to data on interest yet in addition the important mechanical foundation also (Lawler, Mohoma and Ledford, 1995). A significant test for administrators building up a HPWPs is to make a data framework that gives employees information that is ideal and applicable to their specific work measure, that they can impact actually by one or the other exhausting or retaining exertion, and that they can comprehend (Konrad, 2006). Information Development is the twin sister of Information Sharing (Snell, Bohlander and Vohar, 2010). Improving workers' information implies a promise to preparing and advancement. The preparation ventures are fundamental in a high-contribution association since when employees are settling on significant work environment choices, it is significant that they have what it takes and capacities to settle on the correct choices (Konrad, 2006). At the point when prizes are associated with execution, workers normally seek after results that are commonly helpful to themselves and the association. Hence, interfacing prizes to organizational execution likewise guarantees reasonableness and will in general zero in employees on the association (Lawler, Mohoma and Ledford, 1995). Similarly, significant execution-based prizes guarantee that employees share in the additions that outcome from any exhibition improvement.

\section{HPWS and employees' perspectives}

High-Performance Work System (HPWS) is contended, by means of its impact on employees, to bring about an upgrade of execution. Notwithstanding, the linkages from HPWS to worker perspectives and practices lastly organizational execution has barely been tried up until now (Takeuchi, Chen and Lepak, 2009). The examinations which researched what impact HPWS has on employees, expected an effect on a few worker results, for example, commitment, work fulfillment, and organizational citizenship behavior (OCB) (Boselie, 2010; Takeuchi et al., 2009; Macky and Boxall, 2007).
In this examination, the attention will be on the impact of HPWP on affective commitment. Affective commitment can be characterized as 'the worker's passionate connection to, recognizable proof with, and association in the association' (Meyer and Allen, 1991). Boselie (2010) expressed that affective commitment, which is here and there additionally marked organizational commitment, is an attractive HR result for associations. Appelbaum et al., (2000) for instance contended that submitted laborers will be bound to invest additional energy into accomplishing authoritative objectives. As indicated by Boselie (2010) the two different segments of commitment, normative and continuance commitment, may reflect negative employees' mentalities, and dependent on the suspicion that HPWS prompts a better by means of positive worker perspectives, it is for this record that the researchers decided to zero in on the affective commitment.

Concerning all the more explicitly how HPWS is required to prompt employees' perspectives it is contended by for instance Ramsay et al. (2000) and Takeuchi et al. (2009) that the impression of the association and its goals are of significance. Takeuchi et al. (2009) contended that HRpractices will convey signs to employees about what is esteemed by the association and the utilization of HPWS could give workers the sign that the association really focuses on them. HPWS practices might be seen as worker focused and engaging. Thusly, workers locate that those practices give openings and advantages that address their issues and these outcomes in employees taking activities without anyone else and show unwaveringness and eagerness for their manager. Ramsay et al. (2000) contended that when employees see their association really focuses on them, they should accomplish something back for the association.

High-performance Work Practices has been gone into writing as the heap of HR practices which are being utilized in various blend as indicated by culture and business systems of an association. HR practices shape the worker's conduct and disposition toward the association's procedures and objectives (Guzzo and Noonan, 1994). These practices are known by different names as per their utilization and conditions like (a) High-performance management (b) high involvement management (c) high commitment management (Hegan, 2006). The transformation in the working environment builds the prominence of HPWPs, reflecting in the expanding number of associations hurrying to apply some type of HPWS (Nadler, Gerstein, and Shaw, 1992). HPWPs build up a mental connection among employees and managers by making trust in one another (Arthur, 1994; Pfeffer, 1996). Through HPWPs associations give the opportunity to workers to partake in dynamic, acknowledgment of employees' information which instigate inspiration, improve information, expertise, and capacity to perform (Lepak, Liao, Chung, and Harden, 2006). To acquire upper hands, associations utilize these practices to draw in and hold likely workers (Guthrie, 2001; Huselid, 1995; Sun, Aryee, and Law, 2007). The most much of the time use HR management practices as HPWS are high choice 
framework, motivation pay, and the execution board framework, preparing or training (Huselid, 1995), formal correspondence projects to keep workers educated about the firm (Guest, 2001; Guthrie, 2001; Zacharatos, et al., 2005), formal complaint or objection goal framework (Becker and Gerhart, 1996), employees' professional stability, and strategies, for example, no obligatory redundancies. The associations execute those best HRM practices, whose appropriation by and large gives positive results.

As Huselid (1995) contended that firm execution relies on the arrangement of HRM practices with its serious methodologies and on the off chance that it shapes appropriately can give a direct and financially huge commitment to firm execution. Associations utilize these practices to support upper hands (Butler, Ferris, and Napier, 1991; Cappelli et. al., 2010; Wright and McMahan, 1992). Superior associations plan their techniques keeping in view the outer climate and business systems of the association. The fundamental focal point of these constructions is to make the connection between a few plans include like association structure, reward, dynamic, data framework, and errand (Lawler et al. 1995). Associations need to embrace a HR framework that underpins their authoritative methodologies and qualities (Toh et al, 2008). The HRM framework can't be effective until or except if the associations inside social climate and its way of life, design, methodologies, and cycle won't uphold one another (Sparrow and Pettigrew, 1988). As per a few analysts, because of these practices, employees show their positive conduct toward the association looking like commitment. (Appelbaum, 2000; Settoon, Bennett, and Liden, 1996).

Human asset practice in the association is vital in light of the fact that it encourages the work framework to have highperformance. Accordingly the administration needs to keep up the inner consistency in HRM which is normally influenced by the truth of key pressures in associations due to the contending interests of the various partners in the organization who assume a significant part in running the association (Boxall and Purcell, 2008). A portion of the human asset practices that improve the exhibition of the framework and ought to be grasped in the association incorporate the utilization of group based authoritative designs that think about of the individual laborers, critical thinking gatherings, methodologies for empowering better correspondence that will help the employees and the board to impart viably and address the issues influencing them (Lawler et al., 1995). The stuff ought to be capable to show uncommon frameworks benefit the association, basically in key regions, for example, work commitment, organizational identification, and creativity. Sub-measurements of a high-performance work framework, as characterize by Oladapo and Onyeaso (2013), are organizational and work climate human asset practices and legitimacy based HR gauges. The sub-measurements of an high-performance work framework empower the human resource management to develop components of the framework that are coordinated into the cycles of HR without essentially changing the entirety of the HR practices in a specific accomplishment. Strategy based practice makes it feasible for the association to place into activity the irregular sub-measurements and characterize calculable models for the assessment of this specific human asset framework for their association.

\section{Commitment}

Meyer and Allen (1996) distinguish three segments of commitment: affective commitment, continuance commitment, and normative commitment. Affective commitment is characterized as people feeling nearer to the association sincerely and having contribution with the association and its objectives. The employees who have solid affective commitment keep on working in the association since they need to. At the point when employees feel that the association is liable for them, for example, offering compensations higher than the business normal, they will in general respond with inspirational perspectives toward the association, including emotional bonds and sensations of faithfulness. Continuance commitment is additionally an ability to stay inside the association in light of the significant expense of quitting and the benefits of remaining. The other occupation options aren't attractive as it is presently, however in the event that they have a superior bid for employment in future, they don't stop for a second to surrender their positions. Normative commitment is the commitment that an individual accepts that morally they need to work inside the association. A sensation of commitment to their work environment and high devotion is found in employees. As they would like to think, such a thought as to leave their association has not concurred. They stay with the association since they should (Allen and Meyer, 1996). The variety and nature of ventures which are led on employees and furthermore the lack of perceived better options are the components influencing the continuance commitment. In addition, the social conditions can prompt continuation commitment. For example, if a worker was experienced childhood in a family whose individuals were faithful to their association in their working life, the individual would likely feel a commitment to remain in that association.

The forerunners prompting affective commitment are isolated into 4 classifications: personal characteristics, job characteristics, work experiences, and structural characteristics (Allen and Meyer, 1996). Work encounters are the best ones to make affective commitment. Since it satisfies employees' mental requirements to feel good and capable inside the association. Authoritative dependability, receptiveness to groundbreaking thoughts, value, job, and reason clearness address the issues of employees' inclination agreeable in the work environment. Then again, a difficult work, trouble of objectives, criticisms made by the administration, and interest in choices lead individuals to feel equipped. As per Allen and Meyer (1991) study, which was executed by a college and two assembling firms, the employees submit genuinely to the associations on the off chance that they feel skillful and agreeable in their work place. 
On the off chance that and just in the event that it is conceivable to make fearlessness inside the association is by fulfilling the social requirements of employees. The employees feel as they are esteemed and structure a good discernment inside (Rhoades, et al., 2001). In writing, the positive impression of workers about the association is called perceived organizational support. Supportive organizations have a few attributes, for example, being available to inventive thoughts, offering significance to solid correspondence, and a value way to deal with all employees. The more people feel that they are upheld by the association; they bond all the more genuinely to the association (Rhoades, et al., 2001).

\section{Related Studies}

Paul and Anantharaman (2003) led an examination on programming experts in India and found that HRM practices, for example, worker inviting workplace, vocation improvement, advancement arranged evaluation, and thorough preparing showed a critical positive relationship with organizational commitment. In outline, high-performance work practices (HPWPs) that animate employees capacity, worker inspiration, and worker chance to take an interest (AMO) are considered to add to employees optional exertion. Thus, optional exertion is thought to shape the reason for proficiency, adaptability, and social authenticity in the association (Boxall and Purcell, 2008).

The investigation led by Boselie (2010) tries to introduce an exact investigation of the impact of high-performance work practices on commitment and citizenship conduct in the Dutch medical services area. The aftereffects of the investigation propose that organizational citizenship behavior (OCB) can be expanded by HPWPs that improve the chance to take an interest. The examination additionally showed that possibly amazing HR intercessions, for example, employees association in the enrollment and choice of new partners and worker inclusion in dynamic on departmental issues could encourage establishing a high-performance work atmosphere among employees. A medical services association's most significant resources are its human resources and in this way affective commitment and organizational citizenship conduct in the workers is pivotal for the medical services area.

In the investigation directed by Paré and Tremblay (2001) which looks to dissect the turnover expectations among Information Technology experts, it was seen that organizational citizenship practices are contrarily identified with stopping aims. HR practices of an association that gives workers adequate assets and occasions to improve their abilities for example capability advancement, perceive singular commitments, support achievement of new degrees of obligation, and strengthening of employees brings about a more elevated level of affective commitment among its profoundly gifted experts prompting low turnover goals. Further, it was discovered that nonmonetary acknowledgment, competency advancement, reasonable prizes, and data sharing practices, are adversely identified with turnover goals.

A few researchers discovered proof in their examination for the significance of employee's discernment and their positive involvement in HPWS. For instance, Takeuchi et al. (2009) found that the degree to which employees see their associations as esteeming and thinking often about their workers' prosperity, their anxiety for workers' atmosphere, intervened the positive connection between HPWS, work fulfillment, and affective commitment. HPWS was found to decidedly impact the view of workers that their foundation thinks often about its employees. Thusly, this brought about workers being more happy with their work and feeling more dedicated to their association. Workers' trust in administration additionally was discovered to be significant concerning HPWS and employees perspectives. Whitener (2001) alludes to trust in administration to the certainty of the worker in the acknowledgment of authoritative objectives and the certainty employees have in organizational pioneers and the conviction the employees have that organizational activities will be useful for them. Macky and Boxall, (2007) found alongside an immediate beneficial outcome of HPWS on occupation fulfillment, affective commitment, and trust in administration that trust in administration mostly interceded the connection among HPWS and affective commitment. Whitener (2001) found that the positive and huge relationship between employees' impression of authoritative help and obligation to the association was fractional by means of workers' trust in administration. Moreover, Whitener (2001) found that high commitment HR-practices reinforced the connection between perceived organizational help and organizational commitment and between perceived organizational help and trust, which accentuated the significance of HR-practices in affecting employee's attitudes. At last, Appelbaum et al. (2000) explored the impact of the fundamental AMO-build of HPWS on organizational commitment, work fulfillment, and business related pressure. They found, other than the intervening impact of trust in administration, that how much researchers see their responsibilities to be characteristically fulfilling (for example testing and expecting them to utilize their abilities) intervened the beneficial outcomes of HPWS on organizational commitment and occupation fulfillment.

The investigation of Estigoy and Sulasula (2020) investigated factors influencing workers commitment in the work environment of private and public higher education establishments. Both private and public comprehend the objectives of the association, a longing to stay a part, merit dependability, and perceived that the commitment of the employees prompts high profitability to the association. Commitment influences the association and the individual. Submitted workers will want authoritative enrollment and even apply additional push to secure the assets of the organization. A submitted employee is straightforwardly identified with alluring work results or execution, fulfillment 
on the present place of employment, and less turnover of workers.

In light of the explores referenced above it tends to be contended that a HPWS is relied upon to prompt more fulfilled and submitted employees. Discoveries show when employees see their association, through the HRM framework they use, as mindful and having the wellbeing for the workers, can prompt fulfilled and submitted workers. Moreover, the discoveries of Appelbaum et al. (2000) contended the significance of inborn prizes affecting employees mentalities. Executing a HPWS can prompt all the more testing and intriguing work and these characteristic compensations consequently lead to more fulfilled and submitted employees.

\section{Theoretical Framework}

Boselie, Dietz, and Boon (2005) expressed that HPWS and its various structures, for example, High Involvement Work Systems depend on the AMO-hypothesis. Also, the models which are relied upon to impact results through the AMO factors depend on the basic standard of arrangement: the executives and employees interests should be adjusted (Boxall et al., 2008). Thus, it is normal that all organizations will profit by arrangements and practices that assist them with adjusting their advantage to those of workers.

When looking further into detail at AMO, this hypothesis alludes to the Ability (A), Motivation (M), and opportunity (O) of employees which should be impacted (Boxall et al., 2008). The capacity factor of the condition refers to the way that a worker should have the option to do the work. The degree to which employees can do the work relies to a great extent upon people's knowledge, instruction, and life (counting work) encounters (Boxall et al., 2008). The work of the HR division of the association is to enroll and choose people with the correct capacities for the work. As indicated by Boxall et al. (2008) play the quality and amount of affectations offered a significant part in pulling in the correct employees just as the degree to which the enlistment exercises are imaginative and proactive. It is contended that acceptable enlistment is especially of significance in associations where elevated levels of prudence or specific abilities are needed grinding away since the more noteworthy the multifaceted nature of the work the more prominent the change in execution of people (Boxall et al., 2008). At the point when the correct workers are enlisted and chosen their capacities can be additionally expanded by offering a few preparing and advancement openings (Appelbaum et al., 2000).

The skilled workers in the association at that point should be persuaded, by means of incentives, to take an interest in the association and utilize their capacities for the advantages of the association (Appelbaum et al., 2000). The motivators will rouse employees to go to work and to make a sufficient showing. Three kinds of impetuses are contended to accomplish this, in particular extraneous prizes, inborn rewards, and trust (Appelbaum et al., 2000). In view of the hypothesis it is recommended that extraneous prizes matter to workers and when making such rewards dependent upon some type of estimated execution it will assist the firm with performing better (Boxall et al., 2008). Natural rewards, for example, self-governance and intriguing and testing work can likewise impact the inspiration of the employees (Kinnie, Hutchinson, Purcell, Swart and Rayton, 2005). At long last, the significance of an atmosphere of trust experienced by employees can impact workers' inspiration, since it is contended that laborers will be bound to put resources into expanding their abilities and partake in the association when they believe they are viewed as a partner in the association and when they experience a specific degree of employment security (Appelbaum et al., 2000).

The last part of the AMO-hypothesis refers to the way that competent and propelled workers ought to be empowered to partake and to perform. To be successful in improving execution laborers should have the obligation, authority, and the chance to take care of issues and to decide. Employees should have the option to assemble and deal with data themselves and this data thus will be utilized for taking care of issues and to decide (Appelbaum et al., 2000). Having the chance to take an interest and perform incorporates employees having a more noteworthy degree of self-rule and have more command over the choices which influence their work. Moreover, it incorporates employees having the option to utilize assets outside their workgroups and planning their choice with different pieces of the association (Appelbaum et al., 2000).

In view of the basic AMO-hypothesis of HPWS, explicit HR practices, alluded to as HPWS practices, are pointed toward building up the abilities and capacities of a employees, expanding the inspiration for the optional exertion of the worker, and furnishing the employees with the chance to utilize their insight, abilities and different ascribes in their positions. Furthermore, despite the fact that there is no agreement among researchers about which definite HR practices ought to be remembered for a HPWS (Boxall et al., 2008) it is normal that HPWS practices by means of their effect on the capacity, inspiration of workers, and their chance to perform, will add to enhancements in employees performance and in the end organizational performance (Macky and Boxall, 2007).

\section{METHODOLOGY}

The study employed a descriptive research design as this attempt to ascertain the perception of the employees toward the extent of implementation of high-performance work practices. This design is deemed appropriate for the study because it describes and interprets "what is". This is concerned with conditions or relationships that exist, opinions that are held, a process that is going on, effects that are evident, or trends that are developing, although it often considers past events and influences as they relate to current conditions (Best and Kahn 1998). Moreover, the study utilized a survey questionnaire as an approach in data gathering which 
is acknowledged as a cost-efficient and effective means of data collection (Dillman, Smith and Christian, 2009 in Alieto, 2018). It is based on the premise that something is meaningful only if it can be observed and counted. Its key characteristics are numerical data that permit a range of statistical analysis. For the purpose of this study, a questionnaire was adopted from Bae and Lawler 2000; Delery and Doty 1996; Snell and Dean 1992 to gather data on the extent of implementation of high-performance work practices and for affective commitment, measures using the translation by De Gilder, Van den Heuvel and Ellemers (1997) of Allen and Meyer's (1996).

Responses of the study where the empirical data were based are from seventy (70) teachers in Higher Education Institutions in Zamboanga City, Philippines. The respondents have different working environments and are exposed to different organizational strategies, policies, communication, and other factors that would contribute to their perception in the implementation of high-performance work practices.

\section{FINDINGS AND DISCUSSIONS}

1. On the extent to which employees perceive that the organization implements High-Performance Work Practices in terms of Ability, Motivation, and Opportunity?

Responses of the respondents on high-performance work practices in terms of ability show a grand mean value of 3.54 and 3.49 from the private and public HEI respectively with a verbal interpretation of always. As a whole, a grand mean value of 3.50 as always on the statements shows the implementation of practices that directly relative to the ability of the employees. Replies of the respondents on highperformance work practices in terms of motivation show a grand mean value of 3.34 and 3.27 from the private and public HEI respectively with a verbal interpretation of always. As a whole, a grand mean value of 3.29 is always on the statements that show the implementation of practices that relates to motivation presented by the organization to the employees. Accounts of the respondents on high-performance work practices in terms of opportunity show a grand mean value of 3.21 from the private and public HEI with a verbal interpretation of often. As a whole, a grand mean value of 3.21 is often on the statements that show the implementation of practices that relates to opportunity prompted by the organization to the employees. The responses and accounts of the respondents relate to some researchers like, Takeuchi et al. (2009) found that the extent to which employees perceive their organizations as valuing and caring about its employees' well-being, their concern for employees' climate, mediated the positive relationship between HPWP. In addition, HPWP was found to positively influence the perception of employees that their establishment cares about its employees. Another research, Whitener (2001) found that HR-practices strengthened the relationship between perceived organizational support and organizational commitment and between perceived organizational support and trust, which emphasized the importance of HR-practices in influencing employee attitudes. Moreover, Appelbaum et al. (2000) investigated the effect of the underlying AMO-construct of HPWP. They found, besides the mediating effect of trust in management, that the degree to which workers perceive their jobs to be intrinsically rewarding (i.e. challenging and requiring them to use their skills) mediated the positive effects of HPWP.

2. On the perception of the employees towards affective commitment in higher education institutions?

Responses of the respondents on affective commitment show a grand mean value of 2.99 and 3.02 from the private and public HEI respectively with a verbal interpretation of agree. As a whole, a grand mean value of 3.01 as agree on the statements that show commitment in terms of affective towards respective higher education institutions. This supports the study conducted by Tremblay et. al. (2007) which says that HR practices of an organization which provides employees sufficient resources and opportunities to improve their skills i.e., competence development, recognize individual contributions; encourage attainment of new levels of commitment and empowerment of employees results in a higher level of affective commitment. This also recounts the findings of Appelbaum et al., (2000) argued the importance of intrinsic rewards influencing employee attitudes. Implementing an HPWS can lead to for example more challenging and interesting work and these intrinsic rewards in return lead to more satisfied and committed employees.

\section{CONCLUSIONS AND RECOMMENDATIONS}

Given the foregoing findings, the following conclusions are drawn: As a whole, employees are perceived always on the statements that show the implementation of practices that directly relative to the ability of the employees. A comparison between private and public shows that both assessed ability through the given statements as always implemented. Both organizations understand the importance of proper and highquality hiring or recruitment and selection of employees to be able to carry out the job effectively and efficiently. Firms can appreciate the importance of attracting the right employees to materialize the objectives and they recognize that employee's abilities can be further increased by offering several training and development opportunities.

Answers from the respondents by and large, employees perceived always on the statements that show the implementation of practices that identifies with motivation introduced by the association to the workers. Contrasting both private and public shows that motivation through the given explanations is constantly actualized. Associations that raise an incentive in inspiration moderately bring positive results and become more profitable. The firm consistently actualizes a viable examination of performance that can be used in dynamic, prizes or motivations, and advancement of abilities. An inspired worker because of the various introductions of 
builds under inspiration from the administration will create high-performance. Additionally, the foundations set incredible significance on inspiration, for example, giving motivators, cooperation in the association, rewards, putting resources into expanding workers' worth and there is an atmosphere of trust.

Records of the respondents on high-performance work practices regarding opportunity often on the statements that show the implementation of practices that identifies with a promising circumstance provoked by the association to the employees. The association practices a significant component in a promising circumstance when employees are given the duty, authority, and interest to tackle issues and to settle on choices identified with the work. The association makes sure that there is a dependable wellspring of shared data, giving direct criticism about the workers' exhibition and that administration additionally tunes in to the voice of employees in various mediums. The associations are additionally open for an adaptable occupation plan to the employees which are subject to the necessities and the current administrations.

Reactions of the respondents on affective commitment shows concur on the explanations regarding emotional towards separate advanced education establishments. Workers are genuinely joined to, as to be related to, and be engaged with the association. Affectively committed workers will be bound to invest additional energy into accomplishing authoritative objectives and it will prompt a better through sure employee's perspectives. Employees feel that the association is capable toward them, for example, actualizing high-performance practices will in general respond with uplifting perspectives toward the association, including powerful bonds and sensations of faithfulness. Both employees from private and public with solid affective commitment will keep on working in the association, to feel nearer to the association inwardly, to have contribution with and the fulfilment of objectives. A committed employee is straightforwardly identified with alluring work results or performance, fulfilment on the present place of employment, and less turnover of workers.

\section{Recommendations}

The findings previously mentioned serves as the basis upon which the following recommendations are anchored:

1. Organizations ought to include all researchers, employees, and supervisors the same to co-make the usage cycle of HR arrangements easily in the working environment. Associations ought to be enthusiasm in making exercises that will engage employees in the dynamic cycle that can influence the whole firm.

2. The administration ought to have better checking of thorough execution examination and to support its honesty particularly on the outcomes and the introduction to the employees.

3. Supervisors ought to advance a culture of transparency, backing, and building employees through appropriate tutoring and instructing. A framework may build up through booked tutoring and instructing among associates or among worker and supervisor. Also, Rewards can be given to a gathering of employees who have done model commitments in the accomplishment of objectives.

4. Institutions should misuse new advances to quicken high-performance work practices so individuals will be more beneficial and proficient. In an advanced time, it is exceptionally invaluable to construct and keep framework or innovation like solid web associations, organizing, remote organization, profoundly utilitarian work area etcetera to guarantee successful correspondence and accessibility of assets.

5. School heads ought to standardize exercises that form work-connections and backing in the arranging, subsidizing, and execution of such exercises.

6. An inside and out formative subjective examination can be made as a branch of the current examination to additionally research the elements or develops on highperformance work practices, to remember huge relationship and contrast for the reactions as per different factors, what are issues a lot in the execution of HR practices and to investigate different parts of employees' commitment.

\section{REFERENCES}

[1] Allen, N. J., \& Meyer, J. P. (1991). The measurement and antecedents of affective, continuance and normative commitment. Journal of Occupational Psychology, 63(1), 1-18.

[2] Allen, N.J. and Meyer, J.P. (1996) Affective, Continuance, and Normative Commitment to the Organization: An Examination of Construct Validity. Journal of Vocational Behavior, 49, 252-276. http://dx.doi.org/10.1006/jvbe.1996.0043

[3] Appelbaum, E. (2000). Manufacturing advantage: Why highperformance work systems payoff: Cornell Univ Press

[4] Arthur, J. B. (1994). Effects of human resource systems on manufacturing performance and turnover. Academy of Management Journal, 670-687.

[5] Bae, J. and Lawler J.J. (2000) Organizational and HRM Strategies in Korea: Impact on Firm Performance in an Emerging Economy. Academy of Management Journal, 43, 502-517. http://dx.doi.org/10.2307/1556407

[6] Bae, J., \& Lawler, J. J. (2000). Organizational and HRM strategies in Korea: Impact on firm performance in an emerging economy. Academy of Management Journal, 43, 502-519. http://dx.doi.org/10.2307/1556407

[7] Becker, B. and Gerhart, B. (1996). The Impact of Human Resources on Organizational Performance: Progress and Prospects. Academy of Management Journal, 39(4), 779801.

[8] Best, J. and Kahn, J. (2006). Research in Education $10^{\text {th }}$ Edition.

[9] Boselie, P. (2010) Strategic Human Resource Management. A Balanced Approach, McGraw-Hill Higher Education London

[10] Boselie, P., Dietz, G. and Boon, C. (2005) Commonalities and Contradictions in HRM and Performance Research. Human Resource Management Journal, 15, 67-94. https://doi.org/10.1111/j.1748-8583.2005.tb00154.x

[11] Boxall, P. (2012), High- performance work systems: What, why, how and for whom? Asia Pacific Journal of Human Resources, Vol. 50, pp. 169-186.

[12] Boxall, P. and Macky, K. (2007), High- performance work systems and organizational performance: Bridging theory and practice, Human Resource Management Journal, Vol. 19, No.1, pp. 3-23.

[13] Boxall, P. and Macky, K. (2009), Research and theory on highperformance work systems: Progressing the high-involvement 
stream, Human Resource Management Journal, Vol.19, No.1, pp. $3-23$.

[14] Boxall,P. and Purcell,J. (2008),Strategy and human resource management (2nd ed.), New York: Palgrave Macmillan.

[15] Butler, J.E., Ferris, G.R., \& Napier, N.K. (1991). Strategy and human resources management. Cincinnati, OH: South-Western Publishing.

[16] Butts, M. M., R. J. Vandenberg, D. M. DeJoy, B. S. Schaffer, and M. G. Wilson. (2009) Individual Reactions to High Involvement Work Processes: Investigating the Role of Empowerment and Perceived Organizational Support. Journal of Occupational Health Psychology 14 (2). p.122-136.

[17] Cappelli, P., Singh, H., Singh, J. V., \& Useem, M. (2010, March). Leadership lessons from India: How the best Indian companies drive performance by investing in people. Harvard Business Review, 90-97.

[18] Dayarathna, N.W.K.D.K. (2012), Do high performance work systems pay off in Asia? Proceedings, Annual research sessions, International Conference on Business Management, Sri Lanka.

[19] De Gilder, D., Van den Heuvel, H. \& Ellemers, N. (1997). Het 3componenten model van commitment. Gedrag en Organisatie, 10, 95-106

[20] Delery, J.E. and Doty, D.H. (1996) Modes of Theorizing in Strategic Human Resource Management: Test of Universalistic, Contingency, and Configurational Performance Predictions. Academy of Management Journal, 39, 802-835. http://dx.doi.org/10.2307/256713

[21] Dillman, D., Smith, J., \& Christian, L.C. (2009). Internet, mail and mixed-modesurveys:The tailored design method. Hoboken, NJ: John Wiley and Sons. In Alieto, E. (2018). Language shift from English to Mother Tongue: Exploring language attitude and willingness to teach among pre-service teachers. TESOL International Journal, 13(3), 134-146.

[22] Eisenberger, R., \& Rhoades, L. (2001). Incremental effects of reward on creativity. Journal of Personality \& Social Psychology, 81(4), 728-741.

[23] Estigoy, E. and Sulasula, J. (2020). Factors Affecting Employee Commitment in the Workplace: An Analysis. Journal of Education and Practice, 11(27), 160-171. DOI: 10.7176/JEP/11-27-19

[24] Guest, D.E. (2001) 'Human Resource Management: When Research Confronts Theory', International Journal of Human Resource Management, 12: 1092-106.

[25] Guthrie, J. P. (2001). High-involvement work practices, turnover, and productivity: Evidence from New Zealand. The Academy of Management Journal, 44(1), 180-190.

[26] Guthrie, J. P., C. S. Spell, and R. O. Nyamori. (2002) Correlates and Consequences of High Involvement Work Practices: The Role of Competitive Strategy. The International Journal of Human Resource Management. 13 (1). p.183-197.

[27] Guthrie, J.P., Flood, P.C., Liu, W., and MacCurtain, S. (2009), High performance work systems in Ireland: Human resource and organizational outcomes, The International Journal of Human Resource Management, Vol. 20, No.1,pp. 112-125.

[28] Guzzo, R. A., \& Noonan, K. A. (1994). Human resource practices as communications and the psychological contract. Human Resource Management, 33(3), 447-462.

[29] Hegan, S. (2006). Employees` Responses to High-performance Work Systems: Assessing HPWS Effectiveness. Vol.4, p, 23-35

[30] Huselid, M.A. (1995), The impact of human resource management practices on turnover, productivity and corporate financial performance, The Academy of Management Journal, Vol. 38, No. 3, pp. 635-672.

[31] Jackson, S.E. and Schuler, R.S. (1995) Understanding human resource management in the context of organizations and their environments. Annual Reviews. 46, p.237-64.

[32] Konrad A.M. (2006) Engaging Employees through HighInvolvement Work Practices. [Online]Available from: http://iveybusinessjournal.com/publication/engaging-employeesthrough-high-involvement-work-practices/.

[33] Lawler, E.E., Mohrman, S.A. and Ledford, G.E. (1995). Creating high performance organizations: Practice and Results of Employee
Involvement and Total Quality Management in Fortune 1000 companies. [Online]. San Francisco: Jossey-Bas. Available from: https://books.google.lk.

[34] Lepak, D. P., Liao, H., Chung, Y., \& Harden, E. E. (2006). A conceptual review of human resource management systems in strategic human resource management research. Research in personnel and human resources management, 25(1), 217-271.

[35] MacDuffie, J. P. (1994). Human resource bundles and manufacturing performance: Organizational logic and flexible production systems in the world auto industry. Indus. \& Lab. Rel. Rev., 48, 197.

[36] Macky, K., and Boxall, P. (2007), The relationship between high performance work practices and employee attitudes: An investigation of additive and interaction effects, The International Journal of Human Resource Management, Vol. 18, No.4, pp. 537567.

[37] Meyer, J. \& Allen, N. (1990). The measurement and antecedents of affective, continuance and normative commitment to the organization. Journal of Occupational Psychology 63.p122-166

[38] Meyer, J. \& Allen, N. (1990). The measurement and antecedents of affective, continuance and normative commitment to the organization. Journal of Occupational Psychology 63.p122-166

[39] Nadler, D. A., Gerstein, M. S., \& Shaw, R. B. (1992). Organizational architecture: Designs for changing organizations: Jossey-Bass.

[40] Oladapo, V., \& Onyeaso, G. (2013). An empirical investigation of sub dimensions of high-performance work systems that predict organizational innovation. International Journal of Management \& Marketing Research (Ijmmr), 6(1), 67-79.

[41] Paré, G., \& Tremblay., M. (2007). The influence of highinvolvement human resources practices, procedural jus- tice, organizational commitment, and citizenship behav- iors on information technology professionals' turnover intentions. Group \& Organization Management, 32(3), 326-357.

[42] Paul, A.K. and Anantharaman, R.N. (2003) 'Impact of People Management Practices on Organizational Performance: Analysis of a Causal Model', International Journal of Human Resource Management, 14: 1246-66.

[43] Pfeffer, J. (1996). Competitive advantage through people: Unleashing the power of the work force: Harvard Business Press.

[44] Pil, F. K., \& MacDuffie, J. P. (1996). The Adoption of High Involvement Work Practices. Industrial Relations: A Journal of Economy and Society, 35(3), 423-455.

[45] Purcell, J., Kinnie, N., Hutchinson, S., Rayton, B.A., \& Swart, J. (2003). Understanding the people and performance link: Unlocking the black box.

[46] Ramsay, H. and Scholarios, D. (1999) Selective decisions: challenging orthodox analyses of the hiring process. International Journal of Management Reviews. 1(1). p.63-89.

[47] Ramsay, H., Scholarios, D. and Harley, B. (2000) Employees and High-Performance Work Systems: Testing Inside the Black Box. British Journal of Industrial Relations. 38(4). p.501-531.

[48] Settoon, R. P., Bennett, N., \& Liden, R. C. (1996). Social exchange in organizations: Perceived organizational support, leader-member exchange, and employee reciprocity. Journal of Applied Psychology, 81(3), 219.

[49] Snell, S., Bohlander G. and Vohar V. (2010). Human Resources Management-A South Asian Perspective. $2^{\text {nd }}$ Ed. Delhi: Cengage Learning India.

[50] Snell, S.A. and Dean, J.W. (1992) Integrated Manufacturing and Human Resource Management: A Human Capital Perspective. Academy of Management Journal, 35, 467-504. http://dx.doi.org/10.2307/256484

[51] Sparrow, P. R. and A. M. Petigrew (1988a) "Contrasting HRM Responses in the Changing World of Computing," Personnel Management, 20, 2, 40-45.

[52] Sun, L. Y., Aryee, S., \& Law, K. S. (2007). High-performance human resource practices, citizenship behavior, and organizational performance: A relational perspective. Academy of Management Journal, 50(3), 558-577. 
[53] Takeuchi, R., Chen, G. and Lepak, D.P. (2009) Through the Looking Glass of a Social System: Cross-Level Effects of High Performance Work Systems on Employees' Attitude. Personnel Psychology, 62, 1-29.

[54] Takeuchi, R., Chen, G., \& Lepak, D. P. (2009). Through the looking glass of a social system: cross level effects of high performance work systems on employees' attitudes. Personnel Psychology, 62(1), 1-29.

[55] Toh, S. M., Morgeson, F. P., \& Campion, M. A. (2008). Human resource configurations: Investigating fit with the organizational context. Journal of Applied Psychology, 93(4), 864-882. doi:10.1037/0021-9010.93.4.864.

[56] Tremblay, M. , Guay, P. , \& Simard, G. (2001). Organizational commitment and OCB: The role of HR practices. Actes du 10ième Congrès de l'Association Francophone de Gestion des Ressources Humaines [CD-ROM]. Paris: L. Cadin.
[57] Ubeda-García, M., Marco-lajara, B., Sabater-sempere, V. and García-lillo, F. (2013) Does training influence organisational performance? Analysis of the Spanish hotel sector. European Journal of Training and Development. 37 (4). p.380-413.

[58] Ulrich, D. (1997) Human Resource Champions, Boston: Harvard Business School Press.

[59] Whitener, E. M. (2001). Do "high commitment" human resource practices affect employee commitment? A cross-level analysis using hierarchical linear modeling. Journal of management, 27(5), 515-535.

[60] Wright, P. M., \& McMahan, G. C. (1992). Theoretical perspectives for strategic human resource management. Journal of Management, 18(2), 295.

[61] Zacharatos, A., Barling, J., \& Iverson, R. D. (2005). Highperformance work systems and occupational safety. Journal of Applied Psychology, 90(1), 77. 